

\title{
Discussion on 'The Neoproterozoic glacial record in the Río de la Plata Craton: a critical reappraisal'
}

\author{
Special Publications, Vol. 294, 2008, 343-364
}

\author{
ERNESTO PECOITS, NATALIE R. AUBET, MURRAY K. GINGRAS \& KURT O. KONHAUSER \\ Department of Earth and Atmospheric Sciences, University of Alberta, Edmonton, AB T6C 2E3, Canada \\ *Corresponding author(e-mail: epecoits@ualberta.ca)
}

In a recent article, Pazos et al. (2008, p. 343) claim that 'the Zanja del Tigre Formation (Uruguay) represents a glacial influenced succession deposited during the Neoproterozoic, correlative with one of the glaciations described in the Kalahari Craton, prior to Kalahari-Río de la Plata assembly in the proto-western Gondwana margin'. However, we question the two lines of evidence that Pazos et al. (2008) put forth in their paper to constrain the age of this unit and to support a glacial event.

Age of the Zanja del Tigre Formation. Pazos et al. (2008, p. 350, and fig. 4) consider the Zanja del Tigre Formation as part of the Lavalleja Group. This view, however, is incompatible with existing interpretations. According to the latest compilations of the geology of Uruguay (Bossi et al. 1998; Bossi \& Ferrando 2001), the Zanja del Tigre Formation is part of the Carapé Group, which is stratigraphically below the Lavalleja Group. In fact, the Carapé and the Lavalleja groups have long been considered independent lithostratigraphic units (e.g. Bossi \& Navarro 1991), perhaps even belonging to different 'terranes' or 'blocks' (Gaucher et al. 2004).

A recent geochronological study (not available to Pazos et al. 2008, at the time of writing) based on detrital zircons (U-Pb sensitive high-resolution ion microprobe (SHRIMP) data) from the Lavalleja Group and Zanja del Tigre Formation supports the assertion that these units are separate (Basei et al. 2008). The detrital zircons obtained from a metasandstone of the Zanja del Tigre Formation display ages older than $1.8 \mathrm{Ga}$, and Meso- or Neoproterozoic zircons are absent. For the Lavalleja Group, a broad range of detrital zircon ages, between 3.4 and $0.6 \mathrm{Ga}$, was obtained. The agreement between the youngest detrital zircon age obtained in the Basei et al. (2008) study and the $590 \pm 2 \mathrm{Ma}$ (U-Pb SHRIMP) crystallization age of an interbedded basalt (Mallmann et al. 2007) is noteworthy, and certainly indicates a depositional age of c. $590 \mathrm{Ma}$ for at least the uppermost Lavalleja Group. This led Basei et al. (2008) to speculate that the Zanja del Tigre Formation might be part of the basement of the Lavalleja Group, as previously suggested based on field relationships (see above).

Glacial evidence in the Zanja del Tigre Formation. The identification of a thin diamictite horizon in the Zanja del Tigre Formation (Pazos et al. 2008) is questionable. Specifically, the authors invoke glacial influence during the deposition of the diamictite based on the following arguments: 'the metamorphosed and deformed limestones of this unit include a stratigraphically thin $(2 \mathrm{~m})$ interval containing outsized clasts (Pazos et al. 2005) that vary from pebbles to blocks and include gabbros, quartzites (fig. 8e) and granites (fig. 8f). They are isolated, disrupting the lamination in different form to that resulting from tectonic deformation (rotational deformation). Some are very similar to the examples illustrated by Condon et al. (2002) in the compilation of dropstones intervals from Neoproterozoic successions around the world.' In fact, Pazos et al. (2008) used the presence of only two very well-rounded clasts of 1.5 and $3 \mathrm{~cm}$ diameter in a carbonate matrix (their fig. 8e and $8 \mathrm{f}$ ) as supporting evidence of a glacially influenced deposit. Pazos et al. (2008, p. $357)$ then interpreted this interval as containing dropstones that might be regarded as distal glacially influenced deposits or the result of a Heinrich-type event (Heinrich 1988).

We had the opportunity to visit the outcrop described by Pazos et al. (2008) and, despite considerable attempts to confirm their interpretations, we found no evidence of glacial features or even sedimentary lamination. The outcrop is located in a limestone quarry and the quality of the exposure is fairly good, yet both the lower and upper contacts are poorly visible. A detailed analysis of the quarry has shown an outstanding variety of tectonic structures (Fig. 1). Highly deformed mylonitic limestones and schists with boudinaged dykes and veins that cross-cut the original metasediments are the most common features in the quarry. The limestones contain a single distinct mylonitic foliation accompanied by the occurrence of sheath folds and abundant kinematic indicators. The composition of the dykes and veins parallels that of the 'outsized clasts' reported by Pazos et al. (2008, p. 355) and corresponds to granite, gabbro, calcium carbonate and quartz. Both are folded, boudinaged and sometimes rotated, occasionally showing structures that might resemble dropstones. However, their tectonic origin of these 'clasts' is evidenced in the field by the intrusive nature of the bodies that progressively deformed in the proximity of the shear zones. Furthermore, re-analysis of the images shown by Pazos et al. (2008, figs. 8e and f) reveals the presence of grain-tail complexes aligned with the foliation, which clearly suggests a strong shearing component.

In summary, the radiometric data do not support a Neoproterozoic age for the outcrop described by Pazos et al. (2008) and the geological interpretation of the 'glacially influenced diamictite' is inconsistent with field observations.

The authors acknowledge funding from NSERC to K.O.K. and M.K.G., and Alberta Ingenuity to N.A.

\section{References}

Basei, M.A.S., Frimmel, H.E., Nutran, A.P. \& Preciozzi, F. 2008. West Gondwana amalgamation based on detrital zircon ages from Neoproterozoic Ribeira and Dom Feliciano belts of South America and comparison with coeval sequences from SW Africa. In: PAnkhurst, M.J., Trouw, R.A.J., DE 

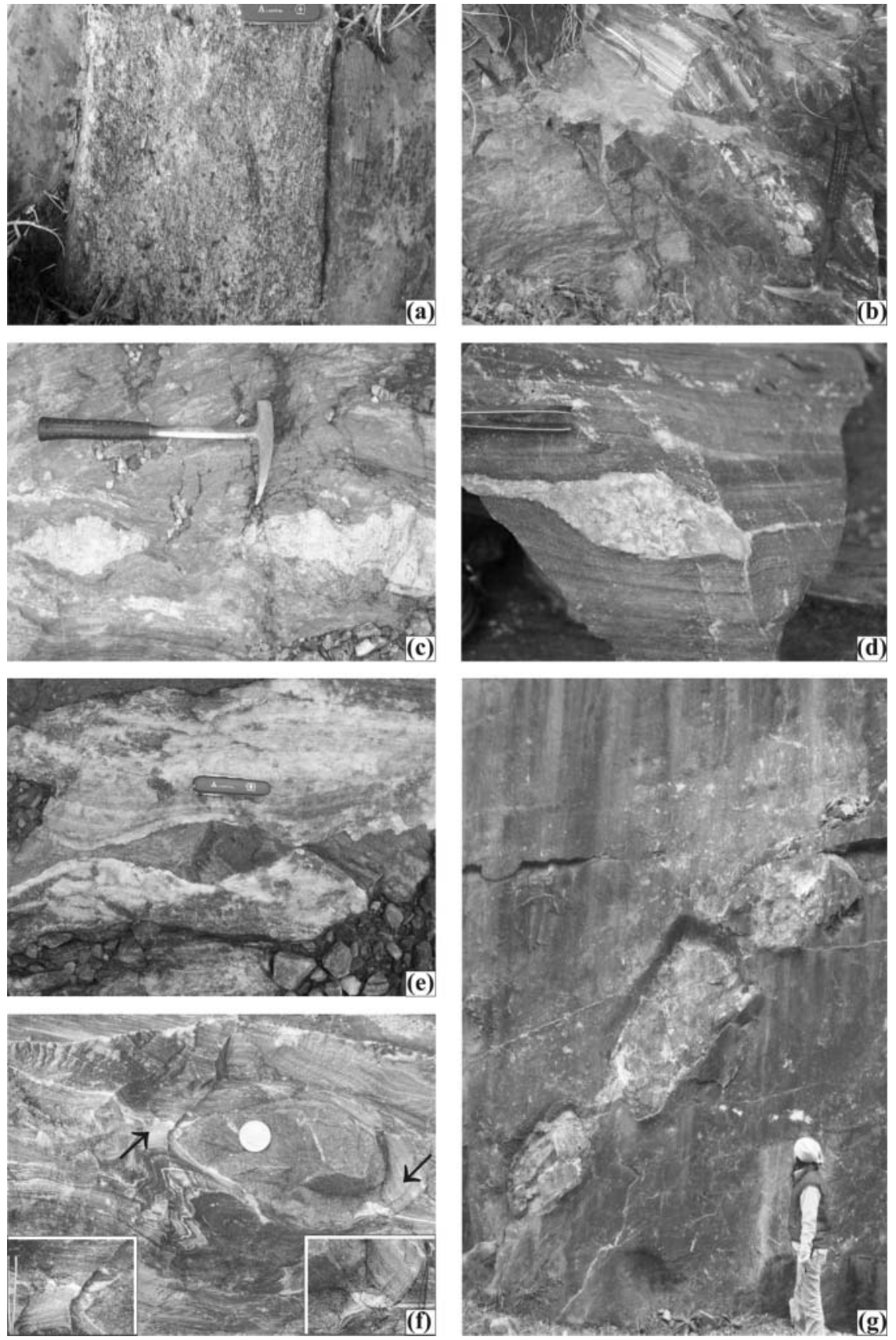

Fig. 1. Structural features of the quarry where Pazos et al. (2008) described limestones containing dropstone levels interpreted as a result of Heinrich events. (a) Undeformed granite dyke with sharp contacts intruding the limestone.

(b) Gabbro-dolerite sill intruding the limestone parallel to foliation. Although exceptional, the presence of metre-long fragments of undeformed granite and dolerite dykes suggests that strain localization preferentially took place along shear corridors in a regional regime. (c) Competent quartz vein boudinaged by ductile shear. (d) A boudinaged quartz vein showing long dynamic recrystallized tails parallel to the mylonitic foliation. (e) Narrow granite dyke displaying pinch-and-swell structure as a result of continuous necking caused by layer-parallel extension. (f) Boudinaged dyke. The granite boudins acted as rigid objects during the shearing, generating long recrystallized tails in response to flow in the host rock. Insets show the partial assimilation of the granite by the limestone as a result of the high strain undergone by these rocks.

(g) Discrete granite boudins formed after continuous necking of a dyke. Although showing identical mineral composition and texture, the difference in scale compared with photographs (a)-(f) should be noted. Scale: knife $9 \mathrm{~cm}$; hammer $40 \mathrm{~cm}$; tweezers $3.5 \mathrm{~cm}$.

Brito Neves, B.B. \& DE Wit, M.J. (eds) West Gondwana: Pre-Cenozoic Correlations Across the South Atlantic Region. Geological Society, London, Special Publications, 294, 239-256.

Bossi, J. \& Ferrando, L. 2001. Carta Geológica del Uruguay. Escala 1:500 000. Versión digital. Geoeditores, Montevideo.

Bossi, J. \& Navarro, R. 1991. Geología del Uruguay. Universidad de la República, Montevideo.

Bossi, J., Ferrando, L., Montaña, J., et al. 1998. Carta Geológica del Uruguay. Escala 1:500 000. Versión digital. Geoeditores, Montevideo.

Condon, D., Prave, A.R. \& Benn, D.I. 2002. Neoproterozoic glacial-rainout intervals: Observations and implications. Geology, 30, 35-38.

Gaucher, C., Chiglino, L. \& Pecoits, E. 2004. Southernmost exposures of the Arroyo del Soldado Group (Vendian to Cambrian, Uruguay): palaeogeographic implications for the amalgamation of $\mathrm{W}$ Gondwana. Gondwana Research, 7, 701-714.
HeINRICH, H. 1988. Origin and consequences of cyclic ice rafting in the northeast Atlantic Ocean during the past 130,000 years. Quaternary Research, 29, $142-152$.

Mallmann, G., Chemale, F., Jr., Ávila, J.N., Kawashita, K. \& Armstrong, R.A. 2007. Isotope geochemistry and geochronology of the Nico Pérez Terrane, Río de la Plata Craton, Uruguay. Gondwana Research, 12, 489-508.

Pazos, P.J., Sánchez Bettucci, L., Pecoits, E. \& Aubet, N. 2005. Carbonates with dropstones in Uruguay: a possible linking lithology with the Namibian and Brazilian Neoproterozoic glacial record. In: IAS International Conference on Glacial Sedimentary Processes and Products, Aberystwyth, Abstacts, 101.

Pazos, P.J., SÁnchez Bettucci, L. \& Loureiro, J. 2008. The Neoproterozoic glacial record in the Rio de la Plata Craton: a critical reappraisal. In: Pankhurst, M.J., Trouw, R.A.J., De Brito Neves, B.B. \& DE Wit, M.J. (eds) West Gondwana: Pre-Cenozoic Correlations Across the South Atlantic Region. Geological Society, London, Special Publications, 294, 343-364. 


\title{
Reply to discussion 'The Neoproterozoic glacial record in the Río de La Plata Craton: a critical reappraisal'
}

\author{
Special Publications, Vol. 294, 2008, 343-364 \\ PABLO J. PAZOS ${ }^{1} \&$ LEDA SÁNCHEZ BETTUCCI ${ }^{2}$ \\ ${ }^{1}$ CONICET-UBA, Departamento Ciencias Geológicas, Facultad de Ciencias Exactas y Naturales, Ciudad Universitaria, \\ Pabellón II (1428), Ciudad Autónoma de Buenos Aires, Argentina \\ ${ }^{2}$ Departamento de Geología, Facultad de Ciencias, Universidad de la República, Iguá 4225 (11400) Montevideo, Uruguay \\ *Corresponding author (e-mail: pazos@gl.fcen.uba.ar)
}

Pecoits et al. (2010) question the stratigraphic and glacigenic origins of a tiny section of the Zanja del Tigre Formation that constitutes the least well-constrained of all confirmed and suspected glacial deposits in the Río de La Plata craton (Pazos et al. 2008, 2010).

Age of the Zanja del Tigre Formation. Pecoits et al. assert that in the 'latest compilations of the geology of Uruguay' the Zanja del Tigre Formation is part of the Carapé Group and not the Lavalleja Group. However, this disregards the contemporaneous stratigraphic scheme of Sánchez Bettucci (1998), which includes the Zanja del Tigre Formation in the Lavalleja Group. This is the stratigraphic scheme followed by Pazos et al. (2008, 2010), as well as by Mallmann et al. (2007) and Basei et al. (2008). We further point out that the geochronological results presented by Mallmann et al. (2007) and Basei et al. (2008) were not available to us at the time of writing. However, we dispute the suggestion that the absence of detrital zircons younger than $1.8 \mathrm{Ga}$ from the Zanja del Tigre Formation necessarily demonstrates a Mesoproterozoic depositional age, significantly older than that of Lavalleja Group (Basei et al. 2008). Some units within undisputed Neoproterozoic sedimentary successions elsewhere in Uruguay and Argentina similarly lack Neoproterozoic detrital zircons (Gaucher et al. 2008). Detrital zircon data can only be used to place lower limits on sedimentation.

Glacial evidence in the Zanja del Tigre Formation. The second point contested by Pecoits et al. concerns the glacial origin of the interval documented in the Zanja del Tigre Formation. There is no disagreement that these rocks have undergone intense deformation in the vicinity of large-scale shear zones during the late Ediacaran (Gray et al. 2008; see also Pazos et al. 2005, 2008). The illustration of 'only two' clasts (quartzite and granite) is a common and accepted number in any other glacigenic paper. However, even if we accept that shearing affected the succession and the presence of deformation tails as correctly pointed out by Pecoits et al., there is no plausible alternative explanation to that of Pazos et al. (2008). We entirely reject the suggestion that the well-rounded quartzite and granite fragments are not clasts but the results of boudinage of intrusions.

\section{References}

Basei, M.A.S., Frimmel, H.E., Nutman, A.P. \& Preciozzi, F. 2008. West Gondwana amalgamation based on detrital zircon ages from Neoproterozoic Ribeira and Dom Feliciano belts of South America and comparison with coeval sequences from SW Africa. In: PAnkhurst, R.J., Trouw, R.A.J., Brito Neves, B.B. \& DE Wit, M.J. (eds) West Gondwana: Pre-Cenozoic Correlations Across the South Atlantic Region. Geological Society, London, Special Publications, 294, 239-256.

Gaucher, C., Finney, S., Poiré, D., et AL. 2008. Detrital zircon ages in Neoproterozoic sedimentary successions in Uruguay and Argentina: Insights into the geological evolution of the Río de la Plata Craton. Precambrian Research, 167, 150-170.

Gray, D.R., Foster, D.A., Meert, J.G., Goscombe, B.D., Armstrong, R., Trouw, R.A.J. \& PAsschier, W. 2008. A Damara orogen perspective on the assembly of southwestern Gondwana. In: Pankhurst, R.J., Trouw, R.A.J., DE Brito Neves, B.B. \& DE Wit, M.J. (eds) West Gondwana: Pre-Cenozoic Correlations Across the South Atlantic Region. Geological Society, London, Special Publications, 294, 257-278.

Mallmann, G., Chemale, F., Jr., Avila, J.N., Kawashita, K. \& Armstrong, R.A. 2007. Isotope geochemistry and geochronology of the Nico Pérez Terrane, Río de La Plata Craton, Uruguay. Gondwana Research, 12, 489-508.

Pazos, P.J., Sánchez Bettucci, L., Pecoits, E. \& Aubet, N. 2005. Carbonates with dropstones in Uruguay: a possible linking lithology with the Namibian and Brazilian Neoproterozoic glacial record. In: IAS International Conference on Glacial Sedimentary Processes and Products, Aberystwyth, Abstracts, 101.

Pazos, P.J., Sánchez Bettucci, L. \& Loureiro, J. 2008. The Neoproterozoic glacial record in the Río de La Plata Craton: a critical reappraisal. In: Pankhurst, R.J., Trouw, R.A.J., DE Brito Neves, B.B. \& DE Wit, M.J. (eds) West Gondwana: Pre-Cenozoic Correlations across the South Atlantic Region. Geological Society, London, Special Publications, 294, 343-364.

Pazos, P.J., Rapalini, A., Sánchez Bettucci, L. \& Tofalo, O.R. 2010. The Playa Hermosa Formation, Playa Verde Basin, Uruguay. In: Arnaud, E., Halverson, G. \& Shields, G. (eds) The Geological Record of Neoproterozoic Glaciations. Geological Society, London, Memoirs (in press).

Pecoits, E., Aubet, N.R., Gingras, M.K. \& Konhauser, K.O. 2008. Ediacaran in Uruguay: palaeoclimatic and palaeobiological implications. Sedimentology, $\mathbf{5 5}, 689-721$.

Pecoits, E., Aubet, N.R., Gingras, M.K. \& Konhauser, K.O. 2010. Discussion on the Neoproterozoic glacial record in the Río de La Plata Craton: a critical reappraisal. Journal of the Geological Society, London, 167, 000-000.

Sánchez Bettucci, L. 1998. Evolución tectónica del Cinturón Dom Feliciano en la región Minas-Piriápolis, Uruguay. $\mathrm{PhD}$ thesis, Universidad de Buenos Aires. 